\title{
Equipment
}

\section{Comparison of fluid warmer performance during simulated clinical conditions}

Nileshkumar Patel MD, Charles E. Smith MD FRCPC, Alfred C. Pinchak PhD PE MD
The study evaluated the warming ability and flow rates associated with four fluid warming devices during pressure driven infusion and during wide open gravity driven roller clamp infusion. Warmers tested were the Astotherm, Flotem IIe, Level 1 System 250 and a modified cardioplegia heat exchanger. Fluids tested were crystalloid, red cells diluted with $200 \mathrm{ml}$, $0.9 \%$ saline, and undiluted red cells. The volume of fluid and outlet temperatures (point where iv tubing would be attached to the patient) were measured for each fluid and compared among warmers for each flow rate condition. For pressure driven infusion of red cells and crystalloid, the System 250, and modified heat exchanger delivered warmer fluids $\left(33-35^{\circ} \mathrm{C}\right)$ at higher flow rates $\left(160-740 \mathrm{ml} \cdot \mathrm{min}^{-1}\right)$ than the Astotherm and Flotem $\left(23-31^{\circ} \mathrm{C}, 44-268 \mathrm{ml} \cdot \mathrm{min}^{-1}, P<0.05\right)$. For gravity driven infusion, the System 250 delivered the warmest fluids (33-36 C, $P<0.05)$ compared with the modified heat exchanger $\left(29-35^{\circ} \mathrm{C}\right)$, Astotherm $\left(26-32^{\circ} \mathrm{C}\right)$ and Flotem (26-27 C). In conclusion, the modified heat exchanger and System 250 were moderately effective (outlet temperture $>32^{\circ} \mathrm{C}$ ) in warming crystalloid and red cells at pressure driven flow rates. Only the System 250 warmed red cells $>35^{\circ} \mathrm{C}$ at gravity driven flow rates. The Flotem and Astotherm were not effective in warming rapidly infused solutions. None of the warmers tested was able to deliver fluids at normothermia $\left(>36.5^{\circ} \mathrm{C}\right.$ ).

\section{Key words}

EQUIPMENT: fluid warmers;

TEMPERATURE: hypothermia.

From the Department of Anesthesia, MetroHealth Medical Center, Case Western Reserve University, Cleveland, Ohio, USA.

Presented in part at the Canadian Anaesthetists' Society Annual Meeting, Edmonton, June 1994.

Address correspondence to: Dr. C.E. Smith at the

Department of Anesthesia, MetroHealth Medical Centre, 2500

MetroHealth Drive, Cleveland, Ohio 44109, USA. Accepted for publication 26th March, 1995.
Ce travail évalue la capacité de réchauffement et les débits produits par quatre appareils de réchauffement destinés à la perfusion sous pression et à la perfusion par gravité. Les réchauffeurs sont l'Astotherm, le Flotem IIe, le Level 1 System 250 et une échangeur de chaleur de cardioplégie modifié. Les liquides étudiés sont les cristalloïdes, des hématies rouges dilués avec $200 \mathrm{ml}$, du physiologique 0,9\% et des hématies non diluées. Le volume de liquide et la température à la sortie (au point d'attache de la tubulure au patient) sont mesurés pour chacun des liquides et comparés entre les réchauffeurs pour chacun des débits obtenus. Pour la perfusion sous pression des hématies et des cristalloïdes, le System 250 et l'échangeur de chaleur modifié fournissent des liquides plus chauds $\left(33-35^{\circ} \mathrm{C}\right)$ à plus haut dédits $\left(160-740 \mathrm{ml} \cdot \mathrm{min}^{-1}, P<0,05\right)$ que l'Asthotem et le Flotem $\left(23-31^{\circ} \mathrm{C}, 44-268 \mathrm{ml} \cdot \mathrm{min}^{-1}, P<0,05\right)$. Pour les perfusions sous gravité, le System 250 fournit les liquides les plus chauds $\left.33-36^{\circ} \mathrm{C}, P<0,05\right)$ comparativement à l'échangeur modifié $\left(29-35^{\circ} \mathrm{C}\right)$, l'Astotherm $\left(26-32^{\circ} \mathrm{C}\right)$ et le Flotem $\left(26-27^{\circ} \mathrm{C}\right)$. En conclusion, l'échangeur de chaleur modifié et le System 250 sont moyennement efficace (température à la sortie $>32^{\circ} \mathrm{C}$ ) pour réchauffer les cristalloides et les hématies à des débits contrôlés par la pression. Seul le System 250 réchauffe les hématies à plus de $35^{\circ} \mathrm{C}$ à des débits contrôlés par la gravité. Le Flotem et l'Astotherm sont inefficaces pour réchauffer des solutions perfusées rapidement. Aucun des réchauffeurs essayés ne fournit de liquides normothermiques $>36,5^{\circ} \mathrm{C}$.

Anaesthetists who care for severely injured trauma patients, or patients sustaining massive intraoperative blood loss, may be required to infuse large volumes of fluids and blood products rapidly in order to restore circulating blood volume. Rapid infusion of unwarmed crystalloid and blood may result in considerable lowering of core temperature that may cause cardiac arrhythmias, coagulopathy, major alterations in response to pharmacological agents, and has been associated with increased mortality. ${ }^{1-5}$ Therefore, most clinicians advocate the use of 
warmed iv fluids during fluid resuscitation of hypovolaemic patients in shock. Several methods to warm $\dot{v}$ fluids have been evaluated. ${ }^{6,7}$ These include immersing coiled $i v$ tubing in warm water bath, passing the $i v$ tubing through heating blocks (dry heat technology), and passing the iv tubing through a conductive surface interfaced with a counter-current heated water bath. The ability of blood warmers to deliver normothermic fluids rapidly may be limited by several factors including limited heat transfer capability of materials such as plastic, limited surface area of the heat exchange mechanism, inadequate heat transfer of the exchange mechanism at high flow rates, heat loss after the $\dot{v}$ tubing leaves the warmer, and suboptimal flow rates due to high resistance of tubing. ${ }^{6,7}$ Because the $40^{\circ} \mathrm{C}$ water bath temperature of countercurrent fluid warmers exceeded the American Association of Blood Bank standards of $38^{\circ} \mathrm{C}$, the Department of Pathology and Transfusion Medicine at our institution was unable to allow the purchase of these counter-current devices for operating room use. Therefore, the Department of Anesthesia, in conjunction with a cardiac perfusionist, developed a modified cardioplegia heat exchange device for rapid intraoperative infusion of crystalloid and blood. The purpose of the present study was to compare the fluid warming capabilities and flow rates of this modified heat exchanger with two commercially available blood warmers at our institution, and one commercially available counter-current heat exchange warmer that had been obtained by another Department. Two common clinical conditions were simulated-pressure driven infusion, and gravity driven infusion with the roller clamp wide open.

\section{Methods}

The commercially available dry heat technology blood warmers tested were those currently in use at our institution, and consisted of the Astotherm (Stihler Electronic Geub, D7000, Stuggart, Germany, Figure 1) and Flotem Ile (Data Chem Inc, Indianapolis, IN, Figure 2) warmers. The Flotem device incorporated the use of proprietary $i v$ tubing $(406 \mathrm{~cm}$ Extension Set, MedMet Medical System, Cincinnati, $\mathrm{OH}$ ) sandwiched in grooves within two rectangular elements which contained the heating element, set at $37^{\circ} \mathrm{C}$. The Astotherm device incorporated the use of proprietary $\dot{v}$ tubing coiled around a circular heating element, set at $38^{\circ} \mathrm{C}$. The commercially available counter-current fluid warmer tested was the Level 1 System 250 (Level 1 Technologies, Rockland, MA, Figure 3) that had been purchased by the Department of Emergency Medicine. The System 250 device pumped water at $40^{\circ} \mathrm{C}$ through a proprietary tube-intube heat exchanger (D-50 disposable set). The inner tube consisted of thermally conductive anodized aluminium,

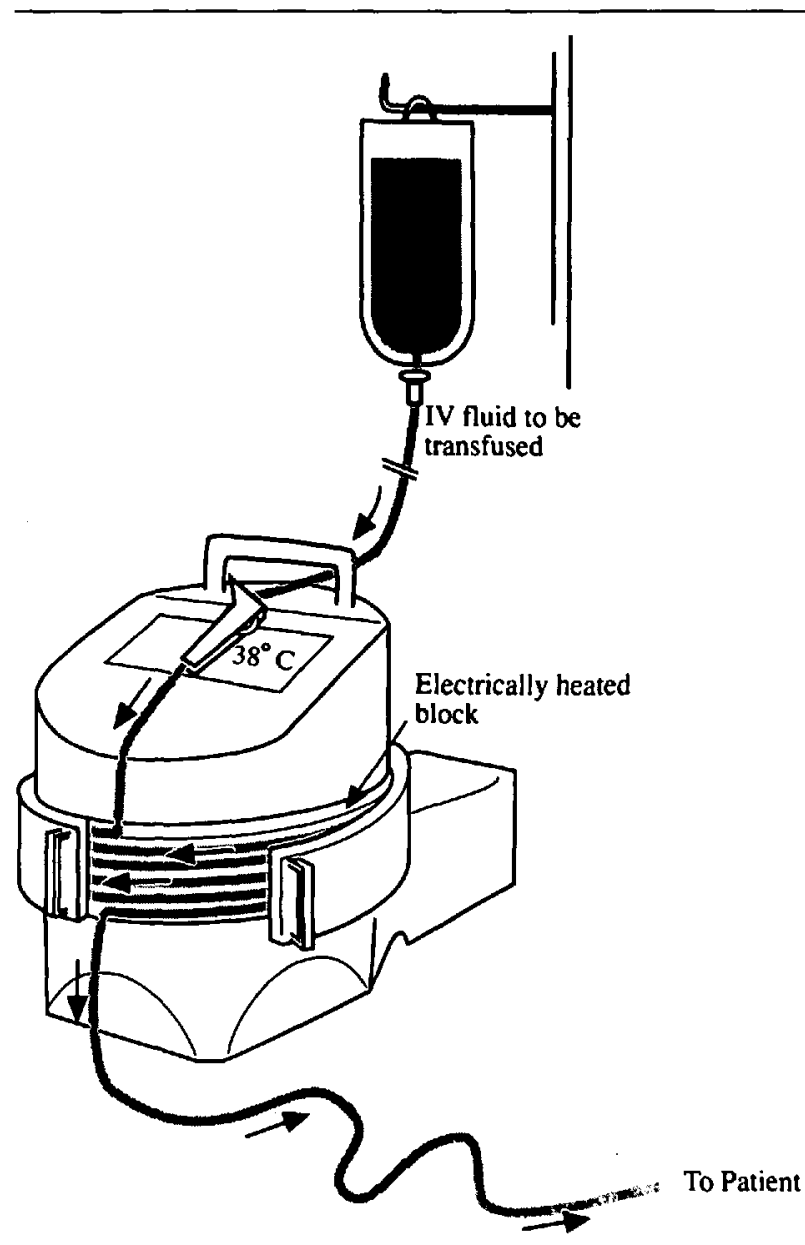

FIGURE 1 Schematic of the Astotherm warmer. This device consisted of $i v$ tubing coiled around a circular heating element.

whereas the $\dot{i}$ fluid flowed through the outer tube in a direction opposite to that of the heated water. The D50 consisted of a standard Y-set, 170 micron filter, automatic air eliminator and $122 \mathrm{~cm}$ patient line, with a priming volume of $50 \mathrm{ml}$. The modified heat exchange device that we developed consisted of a Bentley HE-100 cardioplegia setup $\left(566 \mathrm{~cm}^{2}\right.$ surface area for heat transfer, priming volume $95 \mathrm{ml}$, Bentley Laboratories Inc., Baxter Healthcare Corp., Irvine, CA, Figure 4) through which warm water was passed in a direction opposite to that of the path of the $i v$ fluid. Heat exchange occurred between the proprietary finned large surface area tubing and the stainless steel coil heated by the water bath set at $40^{\circ} \mathrm{C}$ (Pemco Inc., Cleveland, Ohio). The commercial warmers were operated in accordance with manufacturers' guidelines. For the Astotherm and Flotem warmers, Baxter Y-type blood/solution sets with an in-line 170 micron filter (Model 2C7607, Baxter Healthcare Corp.) were used to connect to the proprietary disposables. 


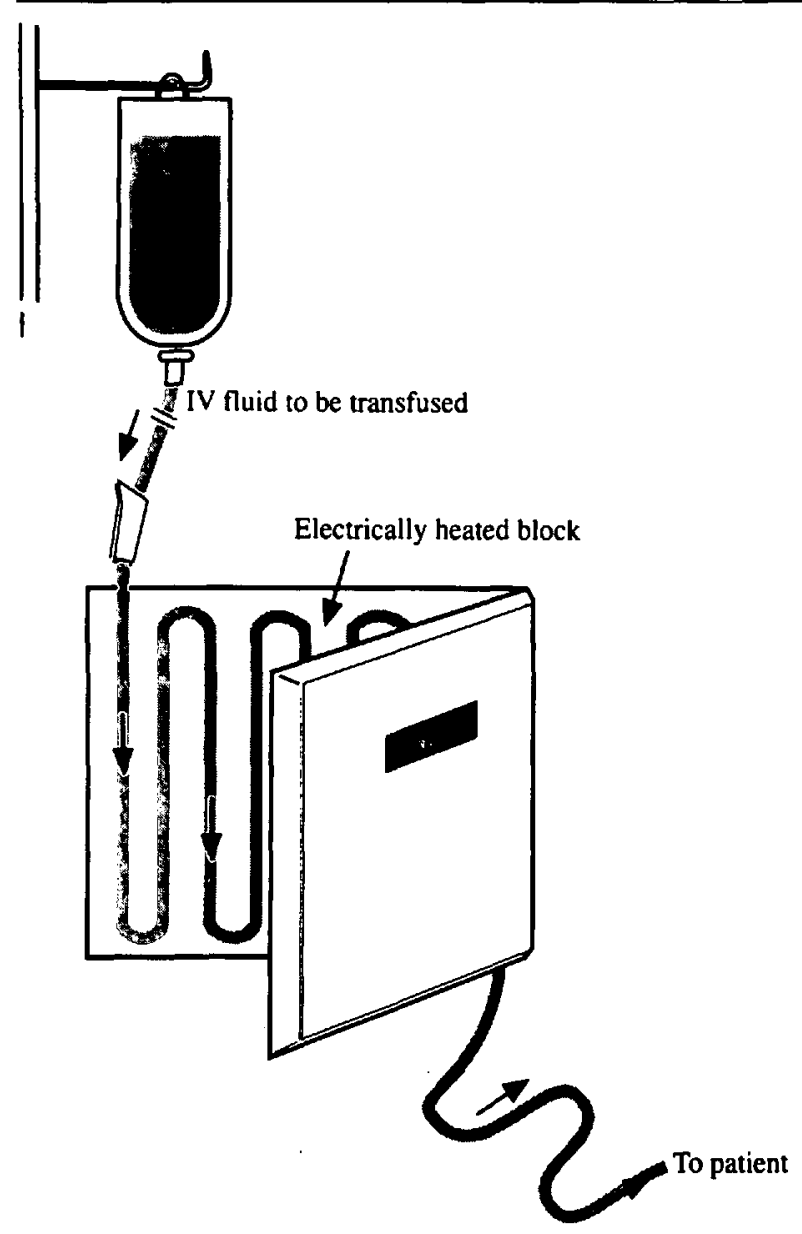

FIGURE 2 Schematic of the Flotem IIe warmer. This device consisted of two aluminum heating plates with a serpentine channel for inserting the $\dot{w}$ tubing.

For the System 250, proprietary disposable sets included all necessary connections. The modified heat exchange device was operated in accordance with the cardiac perfusionist guidelines and consisted of standard $\mathrm{Y}$ tubing (extension EF 13801, $350 \mathrm{~cm}$ long, priming volume 26.5 $\mathrm{ml}$, Medical Product Specialists, Irvine, CA). For the modified heat exchange device, a Pall 40 micron filter (Pall Biomedical Inc., Fajardo, PR) was added for red cell infusions. The Pall filter was not used for crystalloid infusions. The physical and operational elements of each of the fluid warming devices are summarized in Table I. Fluids tested were red cells, red cells diluted with saline $0.9 \% 200 \mathrm{ml}$, and crystalloid (saline $0.9 \%$ or lactated Ringers', $1 \mathrm{~L}$ bags). All red cells were obtained from outdated standard blood bank supply, had been collected in Adsol and were kept refrigerated until use. All crystalloid solutions were at room temperature. In order to simulate the clinical condition of hypovolaemic shock, the entire bag of fluid was infused under constant 300

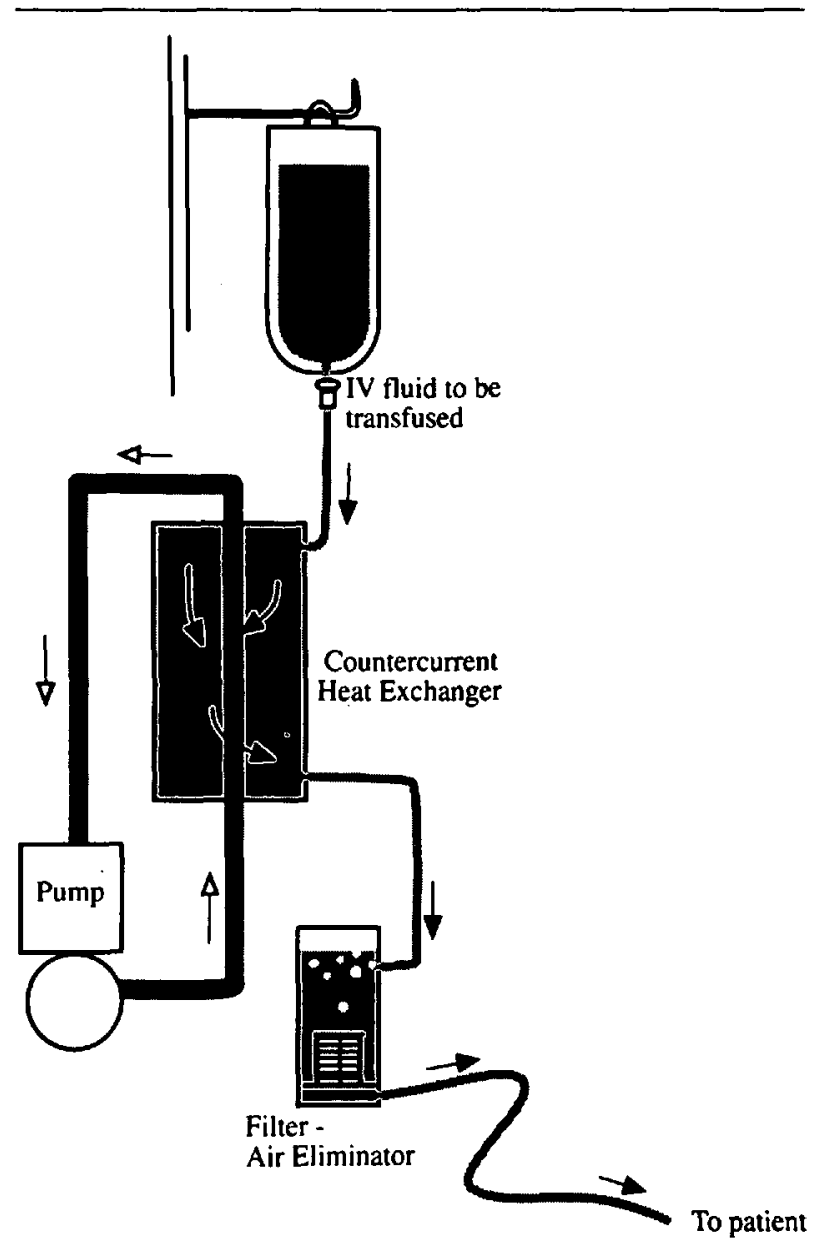

FIGURE 3 Schematic of the Level 1 System 250 warmer. The device consisted of a heater that warmed water to $40^{\circ} \mathrm{C}$ and circulated it through a pump and heat exchange segment with a central tube for water flow. Fluid flowed through the outer sheath which surrounded the water core. Note the filter and air eliminator distal to the heat exchanger.

$\mathrm{mmHg}$ pressure using a pressure bag (Disposable Pressure Infusor, Vital Signs Inc., Totowa, NJ) connected to a constant pressure device (Torrmaster TS2000, Biomedical Dynamics, Burnsville, MN). Each bag of fluid completely infused was considered one fluid run. Fluids were also infused with the roller clamp in the wide open position, but not under pressure (gravity flow, height of column $=1.83$ ). Temperature measurements were made before the fluid entered the warmer (inlet) and at the end of the $i v$ tubing (outlet or point where tubing would be attached to the patient), using rapid-acting in-line Shiley thermistor probes (Shiley Inc., Irvine, CA) that did not obstruct the flow. Temperature probes were calibrated by the manufacturer using standards traceable to the National Bureau of Standards, and were accurate to \pm $0.1^{\circ} \mathrm{C}$. Fluid was infused into cylindrical scored beakers 


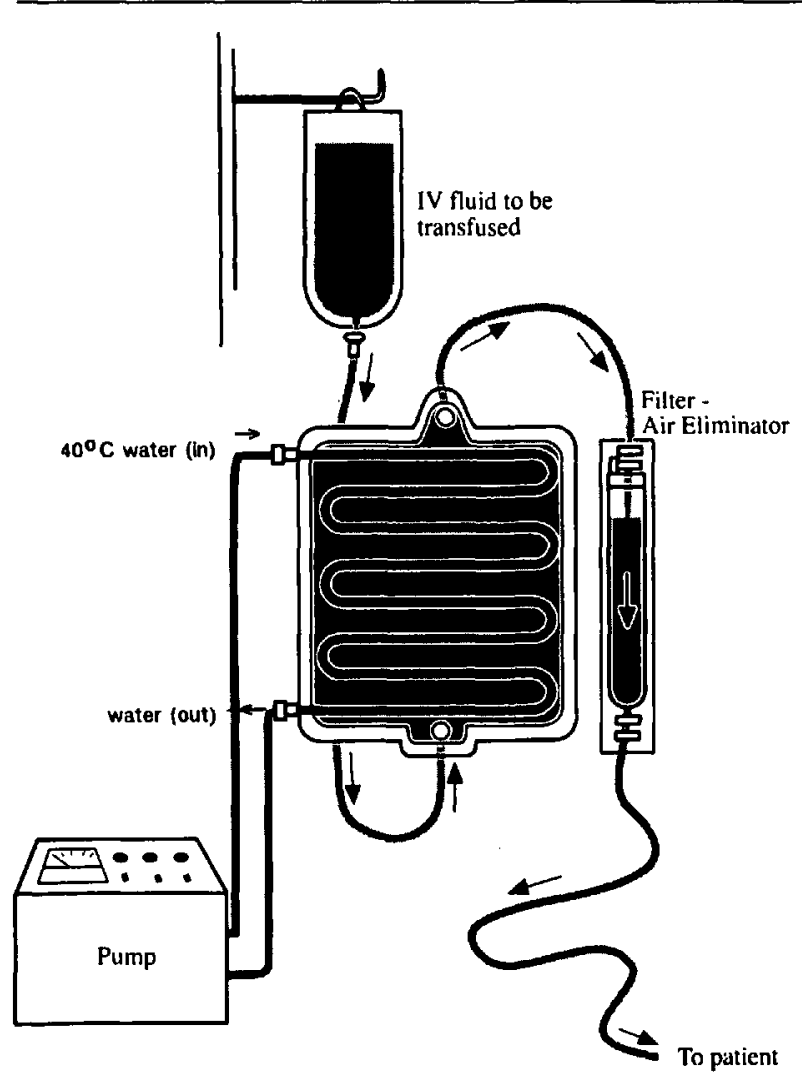

FIGURE 4 Schematic of the modified cardioplegia heat exchange warmer. The device consisted of a $40^{\circ} \mathrm{C}$ water bath that circulated water through the stainless steel cardioplegia heat exchanger.

of varying sizes $(10-3000 \mathrm{ml})$. For each fluid run, inlet and outlet temperatures, and volume of fluid were measured every 10-20 sec for a total of ten measurements or until the bag was empty, whichever came first. Room temperature (Monotherm Model 6510, Mallincrodt Medical, St Louis, MO) was recorded for each fluid run. Minute flow rates were calculated for each measurement interval. Flow rates and temperatures were compared between warmers for each fluid type using analysis of variance (GLM procedure, SAS software), with Tukey's test for multiple comparisons. Results are mean values $\pm \mathrm{SD}$. A $P$ value $<0.05$ was considered significant.

\section{Results}

A total of 108 runs and 767 measurements were done for the warmers as follows: Astotherm - 30 runs, 243 measures; Flotem - 14 runs, 123 measures; System 250 - 27 runs, 180 measures; modified heat exchanger - 37 runs, 221 measures. There were 48 runs with pressure driven infusion and 60 runs with gravity driven infusion. The number of flow rate and temperature measurements per run was $7.4 \pm 3.2$ for fluids under pressure and 6.8 \pm 2.8 for gravity infusion. A total of 40 units of red cells were tested with a haematocrit of $65.9 \pm 9.5 \%$. The average age of the red cells at time of use was $65.4 \pm$ 9.3 days. The room temperature was $21 \pm 0.9^{\circ} \mathrm{C}$ (range 19.4-22. $7^{\circ} \mathrm{C}$ ). Temperature of crystalloid before the warmer (inlet temperature) was $21.0 \pm 1.1^{\circ} \mathrm{C}$. Corresponding values for diluted and undiluted red cells were $17.0 \pm 2.8$ and $13.6 \pm 4.5^{\circ} \mathrm{C}$, respectively. For fluids under pressure, flow rates were faster for each fluid type with the modified heat exchanger and System 250 than with the Astotherm and Flotem devices $(P<0.05$; Table II, III). At these high flow rates, only the modified heat exchanger and System 250 were capable of delivering warm fluids (outlet temperatures $>32^{\circ} \mathrm{C}$ ). However, no blood warmer was capable of delivering fluids at normothermia $\left(>36.5^{\circ} \mathrm{C}\right.$, Table IV, V). With wide open gravity flow, flow rates were faster with the System 250 and modified heat exchanger compared with the other two warmers $(P<0.05$, Table IV $)$.

\section{Discussion}

The present study was designed to simulate two scenarios that clinicians are likely to encounter. In the first, the patient presents with severe circulatory shock due to massive preoperative or intraoperative blood loss. Massive fluid resuscitation via large-bore $\dot{i}$ cannulas (e.g., 8.5 French) is necessary in order to prevent acidosis and irreversible shock. In the second, the fluid and blood volume deficit is not as severe, although ongoing blood loss may necessitate moderately fast infusions with the roller clamp wide open to maintain normovolaemia and haemodynamic stability.

In the first scenario, it is customary to deliver $i v$ crystalloid fluids under pressure immediately in order to restore circulation rapidly. Blood products are given as necessary. At our institution, one litre bags of lactated Ringers' or normal saline are stored at room temperature. Therefore, we chose room temperature as the starting temperature for crystalloid solutions. In the case of massive transfusion, blood is almost always diluted with 100-200 ml normal saline at room temperature, after proper identification of patient and donor information for compatibility. This necessitates a certain time out of the refrigerator, such that the temperature at the start of blood for most transfusions is $10-15^{\circ} \mathrm{C}$. Pressure driven infusions of crystalloids using the Astotherm and the Flotem devices were capable of delivering approximately 250 $\mathrm{ml} \cdot \mathrm{min}^{-1}$, or $15 \mathrm{~L} \cdot \mathrm{hr}^{-1}$, with little heat transfer (outlet temperatures $<25^{\circ} \mathrm{C}$ ). Infusion of $15 \mathrm{~L}$ of $25^{\circ} \mathrm{C}$ crystalloid represents a negative thermal shift of about 180 kcals (thermal shift $=\mathrm{V} \times\left(\mathrm{T}_{37}-\mathrm{T}_{i}\right)$, where $\mathrm{V}$ is the volume of fluid infused or $15 \mathrm{~L}$ in this example, and 
TABLE I Physical and operational elements of the fluid warming devices

\begin{tabular}{lllll}
\hline & Astotherm & Flotemp & System 250 & Heat exchanger \\
\hline $\begin{array}{l}\text { Heat exchange technology } \\
\begin{array}{l}\text { Temperature of heat } \\
\text { exchanger }\end{array}\end{array}$ & Dry heat & Dry heat & Countercurrent & Countercurrent \\
Disposables & $38^{\circ} \mathrm{C}$ & $37^{\circ} \mathrm{C}$ & $40^{\circ} \mathrm{C}$ & $40^{\circ} \mathrm{C}$ \\
& Proprietary & Proprietary & Proprietary & Proprietary \\
Filter - crystalloid & Baxter Y-set & Baxter Y-set & D-50 Y set & EF Y-set \\
& Baxter Y-set & Baxter Y-set & D-50 Y set & None \\
Filter - red cells & 170 micron & 170 micron & 170 micron & \\
& Baxter Y-set & Baxter Y-set & D-50 Y set & Pall, 40 micron \\
Length of $\dot{w}$ tubing after heat & 170 micron & 170 micron & 170 micron & \\
exchanger & $104 \mathrm{~cm}$ & $108 \mathrm{~cm}$ & $192 \mathrm{~cm}$ & $120 \mathrm{~cm}$ \\
\hline
\end{tabular}

TABLE II Flow Rate, $\mathrm{ml} \cdot \mathrm{min}^{-1}$, for $300 \mathrm{mmHg}$ constant pressure driven infusion ( $n=$ number of measures)

\begin{tabular}{llccc}
\hline Fluid type & Astotherm & Flotemp & System 250 & $\begin{array}{l}\text { Heat } \\
\text { exchanger }\end{array}$ \\
\hline$n$ & 121 & 56 & 86 & 62 \\
$\begin{array}{l}\text { Undiluted red } \\
\quad \text { cells }\end{array}$ & $44(14)$ & $86(7) \dagger$ & $161(60) \dagger$ & $234(53)^{*}$ \\
$\begin{array}{l}\text { Diluted red cells } \\
\text { Crystalloid }\end{array}$ & $145(33)$ & $140(54)$ & $203(98)$ & $418(108)^{*}$ \\
\hline
\end{tabular}

Means (SD).

$* P<0.05$ vs all other warmers within fluid type.

$\dagger P<0.05$ vs Flotem and Astotherm within fluid type.

$\ddagger P<0.05$ vs Astotherm within fluid type.

TABLE III Outlet temperature $\left({ }^{\circ} \mathrm{C}\right)$ for $300 \mathrm{mmHg}$ constant pressure driven infusion

\begin{tabular}{lllll}
\hline Fluid type & Astotherm & Flotemp & System 250 & $\begin{array}{l}\text { Heat } \\
\text { exchanger }\end{array}$ \\
\hline $\begin{array}{l}\text { Undiluted red } \\
\quad \text { cells }\end{array}$ & $30.6(2.4) \ddagger$ & $23.4(2.2)$ & $34.0(0.8)^{*}$ & $32.4(3.2) \ddagger$ \\
Diluted red cells & $25.8(2.3)$ & $23.4(3.8)$ & $32.6(1.9)^{*}$ & $32.8(1.4)^{*}$ \\
Crystalloid & $24.7(0.5)$ & $23.7(1.0)$ & $32.7(0.7)^{*}$ & $34.7(2.2)^{\dagger}$ \\
\hline
\end{tabular}

Means (SD).

${ }^{*} P<0.05$ vs Astotherm and Flotem warmers within fluid type.

$\dagger P<0.05$ vs all other warmers within fluid type.

$\ddagger P<0.05$ vs Flotem within fluid type.

$T_{37}-T_{i}$ is the temperature difference between the infused fluids $\left(25^{\circ} \mathrm{C}\right.$ and $37^{\circ} \mathrm{C}$, or $12^{\circ} \mathrm{C}$ in this example). ${ }^{8}$ This will result in a decrease in core temperature by about $3^{\circ} \mathrm{C}$ in a $70 \mathrm{~kg}$ patient (temperature decrease $=$ thermal shift/specific heat $X$ body weight; in this example thermal shift was $-180 \mathrm{kcal}$, specific heat of the body was assumed to be $0.83 \mathrm{kcal}) .^{1,9} \mathrm{It}$ is likely that the negative thermal shift may be even greater for cold blood than for cold crystalloid solutions, although the net effect of infusing cold solutions in the body depends on several factors including tissue blood flow, temperature gradients
TABLE IV Flow rate $\left(\mathrm{ml} \cdot \mathrm{min}^{-1}\right)$ for gravity driven infusion, with the roller clamp wide open ( $n=$ number of measures)

\begin{tabular}{lllll}
\hline Fluid type & Astotherm & Flotemp & System 250 & $\begin{array}{l}\text { Heat } \\
\text { exchanger }\end{array}$ \\
\hline$n$ & 122 & 67 & 94 & 159 \\
$\begin{array}{l}\text { Undiluted red } \\
\quad \text { cells }\end{array}$ & $6(2)$ & $12(1)$ & $41(20) \dagger$ & $119(46)^{*}$ \\
$\begin{array}{l}\text { Diluted red cells } \\
\text { Crystalloid }\end{array}$ & $43(17)$ & $12(1)$ & $100(51) \dagger$ & $99(86) \dagger$ \\
\hline
\end{tabular}

Means (SD).

${ }^{*} P<0.05$ vs all warmers within fluid type.

$\dagger P<0.05$ vs Astotherm and Flotem.

within the body, rate of change of temperature within the body, rate of body heat generation, rate of heat loss to the environment, specific heat of the infused solution and specific heat of the body. ${ }^{2}$ Compared with the Astotherm and Flotem devices, both the System 250 and the modified heat exchanger were capable of delivering considerably warmer cystalloid fluid $\left(33\right.$ and $35^{\circ} \mathrm{C}$, respectively) at a much faster rate $\left(612\right.$ and $740 \mathrm{ml} \cdot \mathrm{min}^{-1}$, respectively). Assuming the same $15 \mathrm{~L}$ fluid requirement, the expected decrease in core temperature in a $70 \mathrm{~kg} \mathrm{pa}$ tient from infusion of these large amounts of crystalloid would be less (negative thermal shift of $15 \mathrm{~L} \times 37-34$, or $-45 \mathrm{kcal})$, in the order of $0.75^{\circ} \mathrm{C}(-45 \mathrm{kcal} / 0.83$ $\times 70$ ). Pressure driven flow rates of diluted red cells were faster than that of undiluted red cells, but slower than that of crystalloid for all fluid warmers tested. Thus, the practice of diluting red cells with $200 \mathrm{ml} 0.9 \%$ saline (at room temperature) can improve flow rates, as well as increase inlet temperature of the red cells to be transfused.

In the second scenario, gravity driven crystalloid infusions with the roller clamp wide open using the Astotherm and the Flotem device resulted in flow rates of approximately $90 \mathrm{ml} \cdot \mathrm{min}^{-1}$ or $5.4 \mathrm{~L} \cdot \mathrm{hr}^{-1}$, with outlet temperatures of 30 and $27^{\circ} \mathrm{C}$, respectively. To heat 5.4 L of crystalloid from 28 to $37^{\circ} \mathrm{C}$ would require $38 \mathrm{kcal}$ 
(5.4 $\times(37-28)$, which could decrease core temperature by about $0.83^{\circ} \mathrm{C}$ in a $70 \mathrm{~kg}$ patient. Compared with the Astotherm and Flotem devices, both the System 250 and the modified heat exchanger were capable of delivering warmer crystalloid fluid ( 36 and $35^{\circ} \mathrm{C}$, respectively) at a much faster rate (270 and $290 \mathrm{ml} \cdot \mathrm{min}^{-1}$, respectively). Assuming the same $5.4 \mathrm{~L}$ fluid requirement, the expected decrease in core temperature would be negligible. Gravity driven flow rates of diluted and undiluted red cells were lower compared with crystalloid for all fluid warmers tested. At these lower flow rates, the performance of the System 250 was better for both diluted and undiluted red cells compared with the modified heat exchanger and the other devices. It is likely that heat loss along the tubing accounted for the decreased efficiency of the modified heat exchanger at flow rates $<120 \mathrm{ml} \cdot \mathrm{min}^{-1}$. Thus, the Astotherm warmer was more effective than the modified heat exchanger in delivering warm diluted red cells (outlet temperature: $31.6^{\circ} \mathrm{C}$ vs $29.2^{\circ} \mathrm{C}$, flow rate $43 \mathrm{ml} \cdot \mathrm{min}^{-1}$ vs $99 \mathrm{ml} \cdot \mathrm{min}^{-1}$, respectively, Table IV, V). However, at lower flow rates with the Astotherm device $\left(6 \mathrm{ml} \cdot \mathrm{min}^{-1}\right)$, there was considerable loss of heat at low flow rates such that the outlet temperature approached that of the room (Table IV, V).

Previous studies evaluating blood warmer performance have focused on the ability of the warmers to heat cold refrigerated fluids. ${ }^{710}$ However, it is our experience that the starting temperature of crystalloid solutions and diluted red cells used for fluid resuscitation in clinical practice were consistently warmer than the refrigeration temperature. Therefore, it was not surprising that the warming capabilities of the System 250 for crystalloid solutions at $600 \mathrm{ml} \cdot \mathrm{min}^{-1}$ in the present study were greater than those reported previously, ${ }^{7,10}$ because the starting temperature of these solutions was that of the room, and not of the refrigerator. Despite the relatively warm inlet temperature for diluted cells $\left(17^{\circ} \mathrm{C}\right)$, the Flotem was still inadequate at delivering warm red cells, although the Astotherm was capable of warming diluted red cells to between 31 and $32^{\circ} \mathrm{C}$. Presson et al. recommended that flow rates of cold blood through the System 250 be restricted to $250 \mathrm{ml} \cdot \mathrm{min}^{-1}$ because warming was inadequate above this rate. ${ }^{10}$ Our data suggest that this recommendation will be easily met since the average pressure driven flow capacity of diluted red cells through the System 250 was approximately $200 \mathrm{ml} \cdot \mathrm{min}^{-1}$, which resulted in outlet temperatures of about $33^{\circ} \mathrm{C}$.

The ideal fluid warmer should be capable of safely delivering fluids and blood products at normothermia at both high and low flow rates. It is clear from the present study that none of the fluid warmers tested was able to deliver consistently fluids at $37^{\circ} \mathrm{C}$ despite the use of countercurrent heat exchange mechanisms and water bath temperatures of $40^{\circ} \mathrm{C}$. Indeed, it is the authors clin-
TABLE V Outlet temperature $\left({ }^{\circ} \mathrm{C}\right)$ for gravity driven infusion, with the roller clamp wide open

\begin{tabular}{lllll}
\hline Fluid type & Astotherm & Flotemp & System 250 & $\begin{array}{l}\text { Heat } \\
\text { exchanger }\end{array}$ \\
\hline Undiluted red & & & & \\
$\quad$ cells & $25.9(1.2)$ & $26.8(1.2)$ & $33.4(2.5)^{*}$ & $31.7(3.1) \dagger$ \\
Diluted red cells & $31.6(2.3) \ddagger$ & $25.8(3.4)$ & $35.4(0.7)^{*}$ & $29.2(2.7)$ \\
Crystalloid & $29.5(2.4)$ & $26.6(1.9)$ & $35.8(0.2) \dagger$ & $35.4(2.1) \dagger$ \\
\hline
\end{tabular}

Means (SD).

* $P<0.05$ vs all warmers within fluid type.

$\dagger P<0.05$ vs Flotem and Astotherm within fluid type.

$\ddagger P<0.05$ vs Flotem and Heat Exchanger within fluid type.

ical impression that maintaining normothermia during massive fluid resuscitation ( $>1 \frac{1}{2}$ blood volumes) in adult patients is almost impossible with any of the fluid warmers tested, and other warming modalities are necessary. It is likely that a water bath temperature of $>40^{\circ} \mathrm{C}$ and/or a more efficient heat transferring material will be required to achieve normothermic conditions. The concern of the American Association of Blood Banks is, however, that blood warmed at temperatures $>38^{\circ} \mathrm{C}$ may result in shifts in red cell osmotic fragility and haemolysis. ${ }^{11}$ Kruskall et al. showed that even with prolonged exposure of old red cells to a $40^{\circ} \mathrm{C}$ heat exchanger, no change in plasma haemoglobin, corpuscular haemoglobin concentration, potassium, ATP, $\mathrm{pH}$ and osmotic fragility occurred compared with unwarmed blood. "Uhl et al. incubated red cells at $37,40,42,44,46,48$, and $50^{\circ} \mathrm{C}$ for up to two hours in constant-temperature waterbath, and showed that even subtle alterations in red cell integrity were not apparent until $46^{\circ} \mathrm{C} .^{12}$ Thus, efficient blood warmers using $42^{\circ} \mathrm{C}$ waterbaths should not damage red cells, and should result in more normothermic fluid delivery in the near future. Incorporation of tubing between the warming unit and the patient to warm the iv fluids (Hotline device, Level 1 Technologies) has been shown to reduce heat loss effectively along the tubing which can occur at flow rates $<75 \mathrm{ml} \cdot \mathrm{min}^{-1}$ with the System $250 .{ }^{13}$

Although the modified heat exchange device was able to deliver pressure driven fluids between 33 and $35^{\circ} \mathrm{C}$ at a much faster rate than the System 250 device, routine use of this modified cardioplegia device over the System 250 cannot be recommended because it took more time to set up, was harder to debubble, had higher disposable costs, and required a separate filter for blood products. Moreover, the commercially available System 250 was capable of delivering $5 \mathrm{~L}$ of diluted red cells (approximately one blood volume in a $70 \mathrm{~kg}$ patient) within 25 min, $15 \mathrm{~L}$ of crystalloid in $25 \mathrm{~min}$, and was associated with higher outlet temperatures than the modified heat exchanger at gravity drive flow rates of approximately 
$100 \mathrm{ml} \cdot \mathrm{min}^{-1}$ (diluted red cells: 35.4 vs $29.2^{\circ} \mathrm{C}, P<$ 0.05 ). Note that the flow rates generated in the present study were assumed to be unimpeded, as is the case of a large bore catheter such as an 8.5 French introducer. Indeed, with the System 250 or modified heat exchanger, a single large bore catheter is all that is needed for most fluid resuscitations. Because of the high flow rates generated by these warmers when used with constant pressure devices, the limiting factor in fluid resuscitation is the time required to identify red cell donor and recipient information, spike and hang the fluid and insure absence of air from the fluid system. In the authors' experience, it is wise to have one individual solely responsible for pressurized infusion of fluids. This individual must utilize extreme vigilance and caution because of the danger of infusing air at these high flow rates. We know of four cases of massive air embolus at other institutions following the use of pressurized infusions. Therefore, it is our opinion that constant pressurized infusion devices not be used unless the patient is in hypovolaemic or haemorrhagic shock, and all air has been removed from the fluid to be rapidly infused. The automatic air eliminator incorporated into the design of the System 250 makes this unit (and subsequent updated units such as the System 500 and newer disposables) somewhat safer, but does not eliminate the risks of massive air embolus. Because of the inadequate outlet temperatures, we cannot recommend Flotem warmers for any perioperative use. Indeed, based on the present study and that of Uhl et al. ${ }^{7}$ that documented the inadequacies of fluid warmers utilizing dry heat technology, Flotem and Astotherm devices are almost never used in the perioperative setting, and have been replaced at our institution by fluid warming devices using countercurrent heat exchange technology.

In summary, $i v$ infusion of large volumes of cold and room temperature solutions may contribute to hypothermia, which in turn may cause coagulopathy, myocardial ischaemia, shivering, and cardiac arrhythmias. ${ }^{1-5,14}$ The System 250 and the modified heat exchanger, which use countercurrent heat exchange mechanisms where a heater warms water to $40^{\circ} \mathrm{C}$ and circulates it via a pump were moderately effective (outlet temperature $>32^{\circ} \mathrm{C}$ ) in warming crystalloid and red cells at pressure driven and gravity driven flow rates. The System 250 was superior to the other three devices in warming diluted and undiluted red cells at gravity driven wide open flow rates (outflow temperature $33-35^{\circ} \mathrm{C}$ ). The Flotem and Astotherm warmers, which use dry heat technology, were not effective in warming rapidly infused solutions, although the Astotherm was moderately effective in warming red cells at lower flows $\left(40-45 \mathrm{ml} \cdot \mathrm{min}^{-1}\right.$, outlet temperatures $31-32^{\circ} \mathrm{C}$ ). Under the conditions of the present study, none of the warmers tested was able to deliver fluids at normothermia.

\section{Acknowledgements}

The authors would like to thank Richard P. Kramer CCP for his assistance with the modified heat exchanger and in-line temperature monitoring, Joan F. Hagen BA for assistance with data analysis, and Judy Johnson MD and Curt Holbrook MD for their interest and enthusiasm in the use of the modified heat exchanger.

\section{References}

1 Morrison RC. Hypothermia in the elderly. Anesthesiol Clin 1988; 26: 124-33.

2 Gentilello LM, Cortes V, Moujaes S, et al. Continuous arteriovenous rewarming: experimental results and thermodynamic model simulation of treatment for hypothermia. $\mathbf{J}$ Trauma 1990; 30: 1436-49.

3 Hall GM. Body temperature and anaesthesia. $\mathrm{Br} \mathrm{J}$ Anaesth 1978; 50: 39-44.

4 Jurkovich GJ, Greiser WB, Luterman A, Curreri PW. Hypothermia in trauma victims: an ominous predictor of survival. J Trauma 1987; 27: 1019-24.

5 Gentilello LM, Cobean RA, Offner PJ, Soderberg RW, Jurkovish GJ. Continuous arteriovenous rewarming: rapid reversal of hypothermia in critically ill patients. J Trauma 1992; 32: 16-25.

6 Faries $G$, Johnston C, Pruitt KM, Plouff RT. Temperature relationship to distance and flow rate of warmed IV fluids. Ann Emerg Med 1991; 20: 1198-200.

7 Uhl L, Pacini D, Kruskall MS. A comparative study of blood warmer performance. Anesthesiology 1992; 77: 1022-8.

8 Hendrickx HHL, Trahey GE, Argentieri MP. Paradoxical inhibition of decreases in body temperature by use of heated and humidified gases (Letter). Anesth Analg 1982; 61: 393-4.

9 Hardy JD, Milhorat AT, Dubois EF. Basal metabolism of young women at temperatures from $22^{\circ} \mathrm{C}$ to $35^{\circ} \mathrm{C}$. J Nutrition 1943; 21: 383-403.

10 Presson $R G J$ r, Haselby KA, Bezruczko AP, Barnett E. Evaluation of a new high-efficiency blood warmer for children. Anesthesiology 1990; 73: 173-6.

11 Kruskall MS, Pacini DG, Malynn ER, Button LN. Evaluation of a blood warmer that utilizes a $40^{\circ} \mathrm{C}$ heat exchanger. Tranfusion 1990; 30: 7-10.

12 Uhl L, Pacini DG, Kruskall MS. The effect of heat on in vitro parameters of red cell integrity. Transfusion 1993; 33 (Supplement): 60S.

13 Smallman JMB, Morgan M. Evaluation of the Level 1 Hotline blood warmer. Anaesthesia 1992; 47: 869-71.

14 Frank SM, Beattie C, Christopherson $R$, et al. Unintentinal hypothermia is associated with postoperative myocardial ischemia. Anesthesiology 1993; 78: 468-76. 